\title{
Etymology of the Medical Terminology of Opsoclonus Myoclonus
}

\section{Steven Yale ${ }^{1 *}$, Halil Tekiner ${ }^{2}$, Eileen S Yale ${ }^{3}$}

'University of Central Florida College of Medicine, Department of Internal Medicine, Orlando, USA

${ }^{2}$ Department of the History of Medicine and Ethics, Erciyes University School of Medicine, Melikgazi, Kayseri, Turkey. ${ }^{3}$ University of Florida, Division of General Internal Medicine, Gainesville, USA.

Article Info

\section{Article Notes}

Received: March 24, 2020

Accepted: March 31, 2020

\section{*Correspondence:}

Dr. Steven Yale MD, MACP, University of Central Florida College of Medicine Lake Nona, Orlando, FL 32827, USA Telephone No: (715) 383-0928; E-mail: steven.yale.md@gmail.com.

(c) 2020 Yale S. This article is distributed under the terms of the Creative Commons Attribution 4.0 International License
The term "opsoclonus" is derived from Ancient Greek words

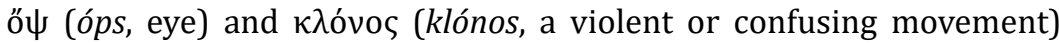
denoting uncontrolled eye movement, while "myoclonus" refers to involuntary and irregular twitching of a muscle or group of muscles. ${ }^{1} \mathrm{We}$ believe that the Polish neurologist Kazimierz Orzechowski (1878-1942) and the pediatrician Stanisław Goździewski (1886-1940) initially presented the term "opsoclonus" in their description of a patient with disorganized conjugate eye movements, at a scientific meeting organized in December of 1924 in the town of Lwów (currently Lviv in western Ukraine), publishing this short report in the chronicle section of the journal Lwowski Tygodnik Lekarski (Lviv Medical Weekly). ${ }^{2}$ The word opsoclonus appeared in the writings of Włodzimierz Mikułowski in April $1925^{3}$ and Witold Tyczka in November $1925^{4}$. It is of interest that Tyczka was a clinical assistant at the University of Warsaw in the clinic of neurologic disease under the aegis of Orzechowski, chief of the Department of Neuroscience ${ }^{3}$ while Mikułowski worked under Władysław Szenajch, Associate and Chief Physician at Charles and Marie Children's Hospital in Warsaw. ${ }^{4}$

Orzechowski used the term opsoclonus as he felt that it better describe and was more closely akin to the phenomenon of myoclonic ataxia. ${ }^{5}$ In his 1927 paper titled "De l'ataxie dysmétrique des yeux: remarques sur l'ataxie des yeux dite myoclonique (opsoclonie, opsochorie)"5 published in the Journal für Psychologie und Neurologie, he discussed and differentiated the ocular hyperkinetic disorders ocular dysmetria (opsochorie) and myoclonic ataxia (opsoclonus):

There are known cases of ocular hyperkinesis, giving the impression of great agitation of the eyeballs, chaotic, variable and almost impossible to analyze. This ocular agitation depends, according to my observations, almost always either on a dysmetry ataxia, which I will deal with here, or on an opsoclonus, the name I gave to myoclonic ataxia, or finally on a combination of these two orders of phenomena. ${ }^{(5, p .1)}$

His 1913 paper titled "Przypadek operowanej tor ieli śrópajeczej móźdźka" (The case of the operated cerebellar endocardial cyst) ${ }^{6}$ has been erroneously and frequently cited and misrepresented in the literature as being the source of the first naming and description of opsoclonus. Orzechowski, in fact, identified in this paper dysmetria and other signs of cerebellar dysfunction, not ocular dysmetria or ocular ataxia in a 21-year-old female. In his 1927 paper he wrote:

It is easy to differentiate the dysmetric incoordination of the eyeballs from opsoclonus (myoclonic ataxia) described by me in 1913 in a work published in Polish and which only Polish authors have dealt with so far (recently Tyczka and Mikułowski). ${ }^{(5, \text { p. 15) }}$ 
Orzechowski eloquently describes in detail the ocular and extraocular findings seen in patients with myoclonic ataxia in 1927:

The diagnosis can be difficult when the disorders in question appear with very great intensity, going as far as "fury of chaotic movements" (opsochorie); it is only during the regression of the phenomenon, that it is then possible to realize the exact nature of the eye disorders. I think it is useful to remind readers beforehand of what constitutes opsoclonus when it acquires a certain intensity, the eyes are in a state of continuous agitation, they are shaken and displaced by very rapid and uneven movements, which generally occurs in the horizontal plane. Often these movements occur in a series, each ending in a sudden elevation, followed by a fall of the eyes, and then a short pause. In the period of remission, when the phenomenon is less marked, the findings appear mainly at the moment when the eyes change their position, whether this change is intentional or reflexive. The findings are especially intense at the beginning of the movement, and throughout its course, the intensity of the tremors decreases and finally stops when the globes reach the point of fixation. Between the horizontal tremors which always predominate, sudden jolts appear occurring in other directions. Throughout the entire clinical picture we always find a few cerebellar symptoms of low intensity (hypotonia of the extremities, spontaneous deviation of the index during Barany's test, tendency to fall, ataxia); but what dominates the clinical picture here are polyclonies [multiple uninterrupted myoclonic muscle jerks], myokymia and trembling of the fingers, chin, lips, blinking, frowning of the forehead, and even difficulty standing and walking as a result of tremor of the muscles of the trunk and lower extremity. ${ }^{(5, p .15)}$

It was not until 1962 that Marcel Kinsbourne (1931-) described in six male and female infants with encephalopathy, myoclonus and "dancing eyes" or opsoclonia characterized by rapid, involuntary, irregular, rotational and disorganized conjugate movements of the eyes. ${ }^{7}$ He called this syndrome myoclonic encephalopathy ${ }^{7}$ and in recognition of Kinsbourne's description, the disease was eponymously named in his honor.

A variety of terms has been used, in addition to Kinsbourne syndrome, throughout the years to describe this phenomenon including dancing eye and feet syndrome $^{8}$, infantile polymyoclonia ${ }^{9}$, encephalopathia myoclonica infantiles ${ }^{10}$, opsoclonic encephalopathy ${ }^{11}$, polymyoclonia-opsoclonus ${ }^{12}$, and ataxia-opsoclonusmyoclonus ${ }^{13}$, the latter a more descriptive term capturing the entire clinical features of the disease. The words opsoclonus-myoclonus syndrome, the currently accepted terminology, first appeared in the literature in 1971 in a paper reported by Tamura and Kuroiwa, titled "Opsoclonusmyoclonus syndrome in acute cerebellar ataxia-clinical and electrophysiological observation of an adult case". ${ }^{14}$

Despite the evolving terminology and eponym attributed to Kinsbourne, it was the comprehensive and detailed clinical observations and description of the disease made by Orzechowski in 1927 that still resonate today.

\section{Conflict of interest by authors}

None

\section{Funding}

None

\section{References}

1. Skinner HA. The Origin of Medical Terms. Baltimore: The Williams \& Wilkins Company; 1949.

2. Orzechowski K, Goździewski S. Lwowski Tygodnik Lekarski Nr 17 XXXVIII pos nauk z dn 19 XII 1924. Lwów Towarzystwa Lekarskiego Lwowskiego; 1924

3. Mikulowski W. Syndrome rare opso-myoclonique observé chez un enfant au cours d'une encéphalite. Arch de méd d enf. 1926; 5: 279-84.

4. Tyczka W. O niezborności mioklonicznej oczu (opsoklonja). Pol Gaz Lek. 1925; 4(46): 967-70.

5. Orzechowski C. De l'ataxie dysmétrique des yeux: remarques sur l'ataxie des yeux dite myoclonique (opsoclonie, opsochorie). Journal f Psychologie und Neurologie. 1927; 35: 1-18.

6. Orzechowski K, Walichniewicz T. Przypadek operowanej torbieli śródpajęczej móżdżka. Lwowski Tygodnik Lekarski. 1913; 13: 219 27.

7. Kinsbourne M. Myoclonic encephalopathy of infants. J Neurol Neurosurg Psychiatry.1962; 25(3): 271-6. doi:10.1136/jnnp.25.3.271.

8. Ford FR. Myoclonic encephalopathy of infants Kinsbourne. In Diseases of Nervous System in Infancy Childhood and Adolescence. $5^{\text {th }}$ ed Springfield Ill Charles C. Thomas Publisher. 1966; 301-3.

9. Dyken P, Kolár O. Dancing eyes, dancing feet: infantile polymyoclonia. Brain. 1968; 91(2): 305-20. doi:10.1093/ brain/91.2.305

10. Brandt S, Carlsen N, Glenting P, et al. Encephalopathia myoclonica infantilis (Kinsbourne) and neuroblastoma in children: a report of three cases. Dev Med Child Neurol. 1974; 16(3): 286-94. doi:10.1111/j.1469-8749.1974.tb03339.x.

11. Corrias A, Nurchi AM, Rossi G, et al. L'encefalopatia opsoclonica nell'infanzia sindrome di Kinsbourne. Pediatr Med Chir. 1985; 7(3): 437-41.

12. Vieira JB, Rosa ED. Polimioclonia-opsoclono: síndrome de Kinsbourne. Relato de um caso. Arq Neuropsiquiatr. 1985; 43(2): 194-7. doi:10.1590/s0004-282x1985000200011.

13. Pinsard N, Pons-Cerdan C, Mancini J, et al. Le syndrome ataxieopsoclonies-myoclonies. Sem Hop. 1981; 57(9-10): 488-94.

14. Tamura K, Kuroiwa Y. Opsoclonus-myoclonus syndrome in acute cerebellar ataxia: clinical and electrophysiological observations of an adult case. Folia Psychiatr Neurol Jpn. 1971; 25(2): 129-35. doi:10.1111/j.1440-1819.1971.tb01495.x. 